\title{
Aerodynamic Decelerators for Planetary Exploration: Past, Present, and Future
}

\author{
Juan R. Cruz ${ }^{*}$ \\ NASA Langley Research Center, Hampton, Virginia, 23681-2199 \\ and \\ J. Stephen Lingard ${ }^{\dagger}$ \\ Vorticity Ltd., Chalgrove, Oxfordshire, OX44 7RW, United Kingdom
}

In this paper, aerodynamic decelerators are defined as textile devices intended to be deployed at Mach numbers below five. Such aerodynamic decelerators include parachutes and inflatable aerodynamic decelerators (often known as ballutes). Aerodynamic decelerators play a key role in the Entry, Descent, and Landing (EDL) of planetary exploration vehicles. Among the functions performed by aerodynamic decelerators for such vehicles are deceleration (often from supersonic to subsonic speeds), minimization of descent rate, providing specific descent rates (so that scientific measurements can be obtained), providing stability (drogue function - either to prevent aeroshell tumbling or to meet instrumentation requirements), effecting further aerodynamic decelerator system deployment (pilot function), providing differences in ballistic coefficients of components to enable separation events, and providing height and timeline to allow for completion of the EDL sequence. Challenging aspects in the development of aerodynamic decelerators for planetary exploration missions include: deployment in the unusual combination of high Mach numbers and low dynamic pressures, deployment in the wake behind a blunt-body entry vehicle, stringent mass and volume constraints, and the requirement for high drag and stability. Furthermore, these aerodynamic decelerators must be qualified for flight without access to the exotic operating environment where they are expected to operate. This paper is an introduction to the development and application of aerodynamic decelerators for robotic planetary exploration missions (including Earth sample return missions) from the earliest work in the 1960s to new ideas and technologies with possible application to future missions. An extensive list of references is provided for additional study.

\section{Nomenclature}

$C_{D_{0}} \quad=$ parachute drag coefficient based on its nominal area, $S_{0}$

$C_{D_{p}} \quad=$ drag coefficient based on the projected frontal area, $S_{p}$

$D_{0} \quad=$ parachute nominal diameter

$h \quad=$ altitude

$m_{v} \quad=$ test vehicle mass

$M \quad=$ Mach number

$q \quad=$ dynamic pressure

$S_{p} \quad=$ projected frontal area

$S_{0} \quad=$ parachute nominal area

ALE $\quad=$ Arbitrary Lagrangian-Eulerian

BLDT $=$ Balloon Launched Decelerator Test

CFD $\quad=$ Computational Fluid Dynamics

\footnotetext{
* Aerospace Engineer, NASA Langley Research Center, Hampton, VA 23681-2199, Juan.R.Cruz@NASA.gov

$\dagger$ Technical Director, Vorticity Ltd., Hampden House, Monument Business Park, Chalgrove, Oxfordshire, OX44 7RW, United Kingdom, Steve.Lingard@Vorticity-Systems.com
} 


$\begin{array}{ll}\text { DCSS } & =\text { Descent Control Sub-System } \\ \text { DGB } & =\text { Disk-Gap-Band } \\ \text { EDL } & =\text { Entry, Descent, and Landing } \\ \text { ESA } & =\text { European Space Agency } \\ \text { FSI } & =\text { Fluid-Structures Interaction } \\ \text { IAD } & =\text { Inflatable Aerodynamic Decelerator(s) } \\ \text { JPL } & =\text { Jet Propulsion Laboratory } \\ \text { MER } & =\text { Mars Exploration Rovers } \\ \text { MOLA } & =\text { Mars Orbiter Laser Altimeter } \\ \text { MPF } & =\text { Mars Pathfinder } \\ \text { MPL } & =\text { Mars Polar Lander } \\ \text { MSL } & =\text { Mars Science Laboratory } \\ \text { NASA } & =\text { National Aeronautics and Space Administration } \\ \text { PEPP } & =\text { Planetary Entry Parachute Program } \\ \text { SPED } & =\text { Supersonic Planetary Entry Decelerator Program } \\ \text { SHAPE } & =\text { Supersonic High Altitude Parachute Experiment } \\ \text { UTTR } & =\text { Utah Test and Training Range } \\ \text { VEM } & =\text { Vortex Element Methods }\end{array}$

\section{Introduction}

ERODYNAMIC decelerators play a key role in the Entry, Descent, and Landing (EDL) of planetary exploration vehicles. In most cases, rigid aeroshells protect the lander during the heat and deceleration pulses of entry. However, such aeroshells do not have sufficient drag area to bring the spacecraft safely to the surface. It is at this point where aerodynamic decelerators are called upon to reduce the speed of the vehicle (often from supersonic to subsonic Mach numbers) and complete the descent and landing portions of the EDL sequence. Table 1 presents a list of Western ${ }^{\ddagger}$ past, present, and future planetary exploration missions that have or will employ aerodynamic decelerators.

Although the above description of the purposes of aerodynamic decelerators seems to imply that they are limited to functioning as deceleration and terminal descent velocity control devices, this is far from the truth. Aerodynamic decelerators serve multiple purposes that must be clear in the engineers' minds as they design, develop, and qualify the spacecraft. Some of these purposes include: deceleration (often from supersonic to subsonic speeds), minimize descent rate, provide specific descent rate (so that scientific measurements can be obtained), provide stability (drogue function - either to prevent aeroshell tumbling or to meet instrumentation

Table 1. Western planetary exploration missions flown or currently under development using aerodynamic decelerators.

Viking $1 \& 2$

Pioneer Venus, US

Galileo, US

Mars Pathfinder (MPF), US

Mars Polar Lander (MPL), US ${ }^{1}$

Beagle 2, UK ${ }^{1}$

Mars Exploration Rovers (MER), US

Huygens, Europe

Genesis, US ${ }^{2}$

Stardust, US

Phoenix, US ${ }^{3}$

Mars Science Laboratory (MSL), US ${ }^{3}$

${ }^{1}$ Lost during EDL sequence

${ }^{2}$ Parachute failed to deploy

${ }^{3}$ Currently under development
Mars, 1976

Venus, 1978

Jupiter, 1995

Mars, 1997

Mars, 1999

Mars, 2003

Mars, 2004

Titan, 2004

Earth Sample Return from Space, 2004

Earth Sample Return from Comet, 2006

Mars, 2008

Mars, 2010

requirements), effect further aerodynamic decelerator system deployment (pilot function), provide difference in ballistic coefficients (to enable separation events), and provide height and timeline (to allow for completion of the EDL sequence).

In this paper, aerodynamic decelerators are defined as textile devices intended to be deployed at Mach numbers below five, once the heat and acceleration pulses of entry have passed. This definition limits the discussion to

* Numerous Soviet and Russian planetary exploration missions have also used aerodynamic decelerators. Unfortunately, there is almost no literature in English about the aerodynamic decelerators used by these missions. Some information on Soviet Mars missions is presented in reference 1. A survey paper describing the accomplishments of Soviet and Russian engineers in this area would be a welcomed addition to the literature. 
parachutes and inflatable aerodynamic decelerators (IADs, also known as ballutes). Devices that are inflated in space (i.e., before entry) do not fall under the category of IADs as defined here, even though they are often also referred to as ballutes. Such devices must withstand the heat of entry, which places requirements on them beyond those considered in this paper for aerodynamic decelerators.

The paper's focus is on robotic planetary exploration missions, including Earth sample return missions, such as those listed in table 1. Note that this emphasis precludes extensive discussions of aerodynamic decelerators for manned space missions and/or low-altitude Earth operations (e.g., supersonic parachutes operating at high dynamic pressures for weapons delivery). For information on these areas the reader is directed to references 2 through 4 .

This paper is an introduction to the development and application of aerodynamic decelerators for planetary exploration missions from the earliest work in the 1960s, to new ideas and technologies and their possible application to future missions. As the research and applications are reviewed, the technical insights gained from them are discussed. In section II, research and missions up to 1995 are reviewed. This section includes the Viking, Pioneer Venus, and Galileo missions. In section III, missions from the late 1990s to those currently under development for launch by the end of this decade are discussed. This section includes several Mars missions, the Huygens mission to Titan, and two Earth sample return missions. Finally, in section IV, we look forward and point out directions in which additional research and development may support future missions in three areas: Computational Fluid Dynamics (CFD) and Fluid-Structures Interaction Analyses (FSI), large subsonic parachutes, and inflatable aerodynamic decelerators. By necessity this paper is merely a brief overview of the field. We have tried to make up for this limitation by providing an extensive list of references for additional study.

\section{Past}

In this section we review early technology development programs and missions from the 1960s to the 1980s. The technology development programs can be organized in three groups: mission system studies that defined the requirements for planetary exploration aerodynamic decelerators, wind tunnel testing, and full-scale flight testing. With the technology developed in these early programs the first three planetary exploration missions requiring aerodynamic decelerators were flown: Viking to Mars (1976), Pioneer Venus to Venus (1978), and Galileo to Jupiter $\left(1995^{\S}\right)$. As will be shown, the division between technology development programs and missions was not as sharp as it may seem - advances in the understanding of aerodynamic decelerators for planetary exploration were also made during the design, development, and qualification phase of these missions.

\section{A. Technology Development Programs}

Early system design studies (e.g., references 5 to 7 ) specified the functions aerodynamic decelerators would accomplish in planetary exploration missions, identified the range of conditions they would be expected to operate in, and suggested possible system configurations. These system studies were focused on missions to Mars and Venus. In an early study, Worth ${ }^{5}$ identified deceleration, the stabilizing effect of a drogue parachute in the low supersonic and transonic flight regimes, descent time, the need for ballistic coefficient differential to effect heatshield separation, and a low descent velocity as key functions of aerodynamic decelerators for planetary exploration missions. He concluded with a comment regarding the need for a comprehensive test program to fully characterize the performance of the required aerodynamic decelerators in the relevant operating conditions. In a later study, Gillis ${ }^{6}$ noted the operating conditions for aerodynamic decelerators during a Mars mission: Mach numbers up to 2 and dynamic pressures up to $960 \mathrm{~Pa}$ for parachutes, and Mach numbers up to 5 for IADs. The upper Mach number limit for parachutes was established in part due to known inflated stability problems associated with parachutes above Mach 2. For missions to Venus, Gillis stated that "the current technology and that under development for Earth entry should furnish a good background for mission planning, since the higher atmospheric density at Venus should provide entries similar to those on Earth...”. He was correct on this, as the Pioneer Venus mission would prove. At this time IADs were considered to be a viable option for missions to Mars, and Gillis discussed both trailing and attached IADs. In these early system studies both single-stage (i.e., one aerodynamic decelerator) and two-stage systems were considered. These systems were either hybrid IAD/parachute, IAD-only, or parachute-only. Although these system studies were useful in defining the operating environments and requirements for aerodynamic decelerators to be used in planetary exploration, actual performance characteristics had to be obtained by wind tunnel and flight testing.

$\S$ Although the Galileo probe made its entry into Jupiter in 1995, its design and development took place during the 1970 s and 80s. This is why the Galileo probe is included in this section. The loss of the space shuttle Challenger in 1986 delayed the launch of the Galileo mission, and lengthened its trip to Jupiter. 
Wind tunnel tests with the specific purpose of developing parachutes and other aerodynamic decelerators for spacecraft applications started in the late 1950s. Maynard ${ }^{8}$ tested various rigid and flexible Ribbon parachutes at Mach numbers between 1.6 and 3.0. Although the impetus for his work was to support the emerging manned space program, the tests were conducted at conditions of interest to robotic spacecraft. Both rigid and flexible Ribbon parachutes were tested at Earth simulated altitudes from 15 to $37 \mathrm{~km}$. Maynard's results showed that Mach number and parachute porosity were key parameters in the performance of these parachutes. Several types of instabilities were noted, including oscillations of the parachute due apparently to asymmetries in

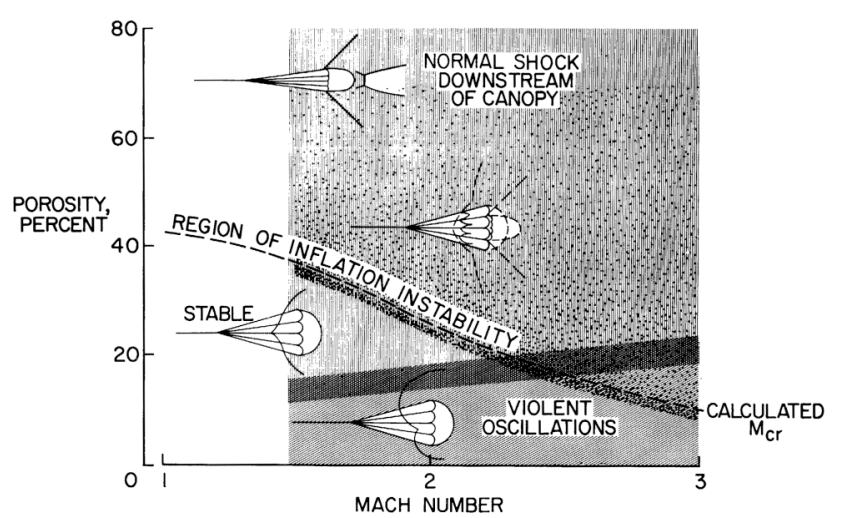

Figure 1. Ribbon parachute stability regions (from ref. 8).

the bow shock wave system, and inflation oscillations in which the parachute partially collapsed and re-inflated. As shown in figure 1 from reference 8 , these regions of instability depend on the parachute porosity ${ }^{\pi}$ and Mach number.

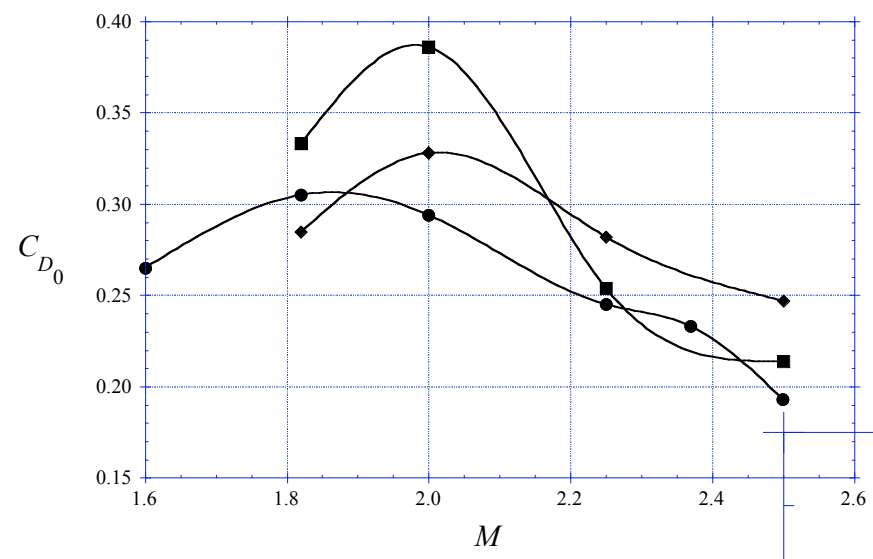

Figure 2. Ribbon parachute drag coefficient vs Mach number (data from ref. 8). Another important observation was the variation in parachute drag coefficient with Mach number. After reaching a peak at Mach numbers between 1.8 and 2, the parachute drag coefficient was shown to decrease with increasing Mach number as shown in figure 2. Increasing porosity also reduced the parachute's drag coefficient. Other wind tunnel test programs (e.g., references 9 and 10) yielded similar observations and additional insights. For example, both references 9 and 10 noted that increasing the suspension line length increased the parachute's drag coefficient. These and other wind tunnel test programs pointed to the challenges of flight testing and developing fullscale parachutes.

In parallel with these efforts to understand the behavior of parachutes, wind tunnel tests of trailing rigid and inflatable aerodynamic

decelerators were being conducted. References 11 through 13 are examples of these test programs. Some of the wind tunnel models tested were simulations of rigid aerodynamic decelerator devices, but others were clearly intended to be IADs in full-scale operation. The hoped-for advantage of these devices over parachutes was that they would not suffer of the instabilities described above. McShera ${ }^{13}$ tested flexible IADs that were inflated by either an internal gas source or external ramair. The IAD shapes tested included a cone balloon, an $80^{\circ}$ cone, and a sphere as shown in figure 3. McShera's results indicated that these IADs provided high drag and good stability characteristics when operating in the supersonic

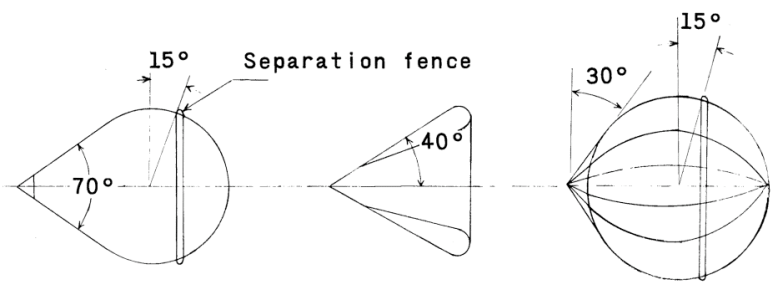

$70^{\circ}$ cone balloon
Sphere

Figure 3. Trailing inflatable aerodynamic decelerators tested by McShera (adapted from ref. 13). region of the towing vehicle's wake. With shorter trailing distances, in the region where the towing vehicle's wake

" Parachute porosity is a measure of the canopy's open area. Maynard ${ }^{8}$ uses the term to describe geometric porosity - the ratio of the open areas of the canopy such as the vent to the nominal parachute area. Another measure of parachute porosity that includes the effect of fluid flowing through the canopy fabric can also be defined - this is usually known as the total porosity. 


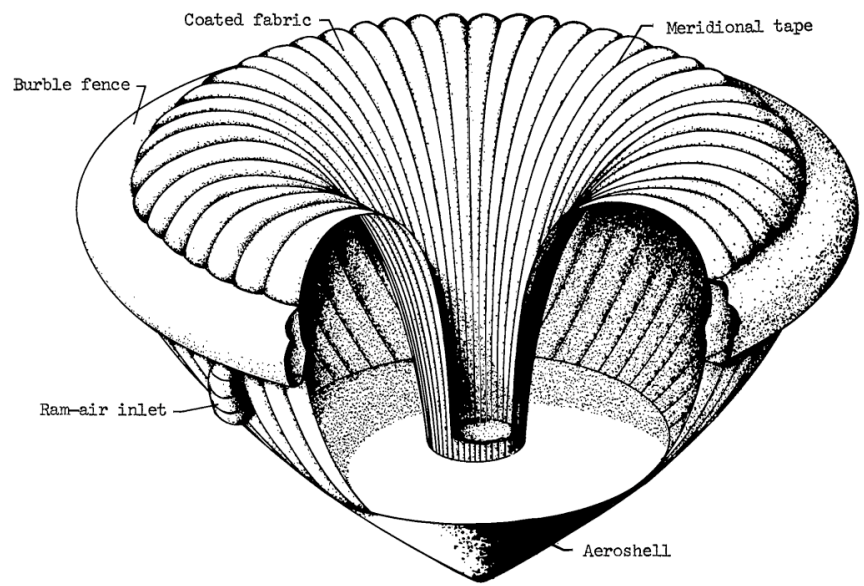

Figure 4. Attached inflatable aerodynamic decelerator (from ref. 17).

is either subsonic or transitioning from subsonic to supersonic the IADs' drag was reduced, and its stability characteristics deteriorated. Attached IADs (figure 4) were also the subject of study and wind tunnel testing. In a series of test programs, ${ }^{14-17}$ attached IADs of $1.5 \mathrm{~m}$ diameter were designed, fabricated, and tested in wind tunnels at Mach numbers up to 4.4. These IADs were inflated by a combination of evaporating liquid to initiate the inflation and ram-air to complete and sustain the internal pressure. Results indicated that these attached IADs had reliable inflation characteristics, high drag coefficients (over 1.0 at supersonic speeds based on frontal area), and were free of undesirable flutter. In spite of the good performance demonstrated in wind tunnel tests by IADs at high supersonic Mach numbers, their development
programs of IADs for planetary exploration were essentially stopped in the mid 1970s. No supersonic flight test programs of IADs for planetary exploration were
conducted. This seems to have happened because the performance requirements of the first set of planetary exploration missions, namely Viking, Pioneer Venus, and Galileo, could be met with parachutes - a more mature technology.

Although wind tunnel testing yielded important information about parachutes operating at supersonic speeds in low-density environments, full-scale flight tests were needed to develop practical systems. In the 1960 s and 70 s, NASA undertook a series of high-altitude, supersonic parachute test programs to develop planetary parachute technology. These programs were named Planetary Entry Parachute Program (PEPP), Supersonic Planetary Entry Decelerator Program (SPED), and Supersonic High Altitude Parachute Experiment (SHAPE). Between these three programs, sixteen high-altitude supersonic flight tests were conducted: five with Ringsail parachutes, three with Cross parachutes, and eight with Disk-Gap-Band (DGB) parachutes. The results of these tests were documented in

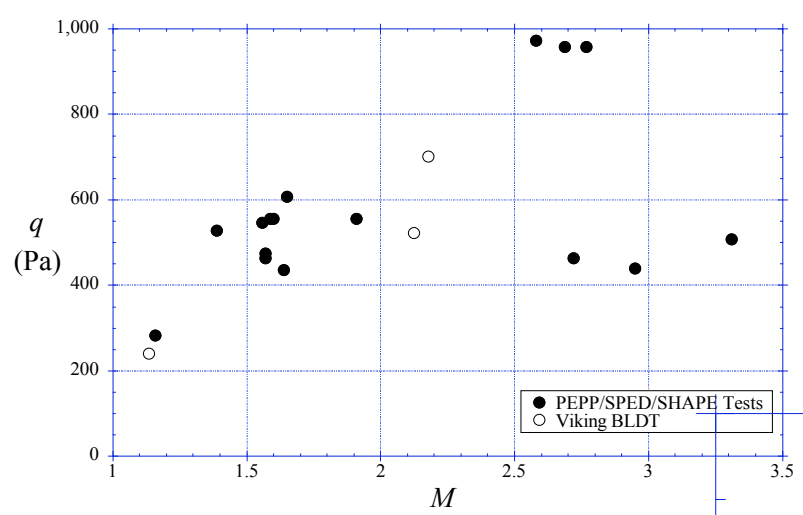

Figure 5. Summary of supersonic parachute flight test experience.

references 18 through 44. A summary of these tests is shown in table 2, and a graph of the test conditions in Mach number/dynamic pressure space is shown in figure 5. These tests were conducted by two tests methods. One

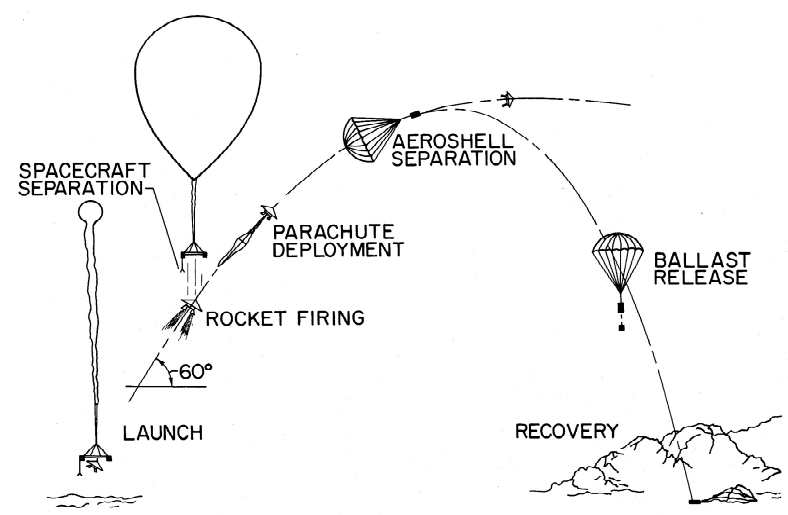

Figure 6. Balloon/rocket test method (from ref. 21). method used a surface-launched rocket, with parachute deployment occurring at high altitude and Mach number. The other method used a balloon to lift the test vehicle to high altitudes. After separation from the balloon a set of rockets fired, accelerating the vehicle to the desired speed for the test. The flight test sequence for the balloon/rocket test method is shown in figure 6 . This second test method proved to be useful for tests in which it was desired to have a blunt-body aeroshell upstream of the parachute. In all of these tests the parachute was deployed by a mortar. The emphasis of these tests was clearly to develop parachute technology suitable for application to Mars EDL. 
Table 2. Summary of PEPP, SPED, and SHAPE flight tests.

\begin{tabular}{|c|c|c|c|c|c|c|c|c|}
\hline $\begin{array}{c}\text { Parachute } \\
\text { Type }\end{array}$ & $\begin{array}{c}\text { Nominal } \\
\text { Diameter } \\
D_{0}(\mathrm{~m})\end{array}$ & $\begin{array}{c}\text { Deployment } \\
\text { Mach } \\
\text { Number } \\
M\end{array}$ & $\begin{array}{c}\text { Deployment } \\
\text { Dynamic } \\
\text { Pressure } \\
q(\mathrm{~Pa})\end{array}$ & $\begin{array}{c}\text { Deployment } \\
\text { Altitude } \\
h(\mathrm{~m})\end{array}$ & $\begin{array}{c}\text { Test } \\
\text { Vehicle } \\
\text { Mass } \\
m_{v}(\mathrm{~kg})\end{array}$ & Successful? & Refs. & Notes \\
\hline Ringsail & 12.2 & 1.64 & 436 & 26.5 & 108 & No & 19 & A \\
\hline Ringsail & 26.0 & 1.16 & 282 & 40.4 & 125 & Yes & 21,27 & B, C \\
\hline Ringsail & 9.5 & 1.39 & 527 & 37.3 & 100 & Yes & 25 & A \\
\hline Ringsail & 16.6 & 1.60 & 555 & 40.2 & 244 & Yes & 35 & B \\
\hline Ringsail & 12.2 & 2.95 & 440 & 52.3 & 127 & Yes & 38 & A \\
\hline Cross & 16.6 & 1.65 & 607 & 39.9 & 257 & Yes & 31 & B \\
\hline Cross & 9.1 & 1.57 & 464 & 41.5 & 109 & Yes & 33 & A \\
\hline Cross & 7.7 & 1.57 & 474 & 40.4 & 98 & No & 33 & A \\
\hline DGB & 9.1 & 1.56 & 546 & 38.9 & 102 & Yes & 20 & A \\
\hline DGB & 19.7 & 1.59 & 555 & 40.7 & 248 & Yes & 28 & B \\
\hline DGB & 12.2 & 2.72 & 464 & 48.3 & 127 & Yes & 29 & A \\
\hline DGB & 12.2 & 1.91 & 555 & 42.7 & 127 & Yes & 34 & A \\
\hline DGB & 12.2 & 3.31 & 508 & 51.4 & 129 & No & 39 & A \\
\hline DGB & 12.2 & 2.58 & 972 & 43.6 & 127 & Yes & 42 & A, C \\
\hline DGB & 12.2 & 2.77 & 958 & 43.6 & 129 & No & 42 & A, C \\
\hline DGB & 16.8 & 2.69 & 886 & 44.3 & 1,193 & No & 43 & A \\
\hline
\end{tabular}

Notes: A - Rocket test method; B - Balloon/rocket test method; C - Reefed

Although not all of these flight tests were successful, the results clearly indicated that large parachutes intended for supersonic deployment in low-density atmospheres could be designed, built, and successfully flown. Several of the parachute performance characteristics observed in wind tunnel tests also appeared in the flight test data. The full-scale parachutes exhibited supersonic inflation oscillations that increased in violence as the Mach number increased. In addition, the tendency of the drag coefficient to decrease at the higher Mach numbers was also observed. In some flight tests problems related to aeroheating were encountered with some parachutes, in particular when operated at Mach numbers above 2.7. With the results of the wind tunnel and flight-test development programs in hand, the groundwork was in place for the development of the parachute system for the Viking mission to Mars.

\section{B. Viking, Pioneer Venus, and Galileo}

The first three planetary exploration missions requiring aerodynamic decelerators are discussed here: Viking to Mars (1976), Pioneer Venus to Venus (1977), and Galileo (1995). A summary of the aerodynamic decelerator system characteristics for these missions (and all other missions discussed in this paper) are given in table 3 . Viking used much of the technology developed in the 1960s and 70s for parachutes operating at supersonic speeds in lowdensity atmospheres as described above. Because of the different operating conditions (transonic deployment), Pioneer Venus and Galileo were able to draw on Earth-based parachute technology for their systems. The EDL system architectures and requirements allowed these missions to be conducted with parachute technology; IADs were not needed.

\section{Viking}

After considering a variety of options, including a two-stage IAD/reefed parachute system, the Viking mission to Mars selected a single, unreefed, DGB parachute to be deployed by a mortar as its aerodynamic decelerator system. $^{45,46}$ This system was considered to be the simplest that would meet the Viking aerodynamic deceleration requirements. The experience obtained with similar systems in the technology development programs was also critical in the selection process.

The development and qualification process for the Viking parachute consisted of four main elements: wind tunnel tests, ${ }^{47-49}$ low-altitude subsonic drop tests,${ }^{50}$ high-altitude flight tests, ${ }^{51-59}$ and mortar tests. ${ }^{60}$ Together, these elements constitute the most extensive, and thoroughly documented, parachute development and qualification program for an unmanned planetary exploration mission, past or present. The data generated by Viking is still extensively used to develop new planetary parachute systems. 
Table 3. Key characteristics of aerodynamic decelerators flown on planetary exploration missions.

\begin{tabular}{|c|c|c|c|}
\hline \multirow{2}{*}{ Mission } & \multicolumn{2}{|c|}{ Parachute } & \multirow{2}{*}{ Deployment Method } \\
\cline { 2 - 3 } & Type & Diameter or Area & Mortar \\
\hline Viking & DGB & $16.2 \mathrm{~m} D_{0}$ & (1) Mortar \\
\hline Pioneer Venus & $\begin{array}{c}\text { (1) Ribless Guide Surface } \\
\text { (2) Conical Ribbon }\end{array}$ & $\begin{array}{c}\text { (1) } 0.76 \mathrm{~m} \\
\text { (2) } 4.94 \mathrm{~m}\end{array}$ & (2) Pilot Parachute \\
\hline Galileo & $\begin{array}{c}\text { (1) Conical Ribbon } \\
\text { (2) Conical Ribbon }\end{array}$ & $\begin{array}{c}\text { (1) } 1.14 \mathrm{~m} D_{0} \\
\text { (2) } 3.8 \mathrm{~m} D_{0}\end{array}$ & $\begin{array}{c}\text { (1) Mortar } \\
\text { (2) Pilot Parachute }\end{array}$ \\
\hline Mars Pathfinder & DGB & $12.7 \mathrm{~m} D_{0}$ & Mortar \\
\hline Mars Polar Lander & DGB & $12.7 \mathrm{~m} D_{0}$ & Mortar \\
\hline Beagle 2 & (1) DGB & (1) $3.2 \mathrm{~m} D_{0}$ & (1) Mortar \\
& (2) Ringsail & (2) $10.0 \mathrm{~m} D_{0}$ & (2) Pilot Parachute \\
\hline Mars Exploration Rovers & DGB & $14.1 \mathrm{~m} D_{0}$ & Mortar \\
\hline Huygens & (1) DGB & (1) $2.6 \mathrm{~m} D_{0}$ & (1) Mortar \\
& (2) DGB & (2) $8.3 \mathrm{~m} D_{0}$ & (2) Pilot Parachute \\
& (3) DGB & (3) $3.0 \mathrm{~m} D_{0}$ & (3) Parachute \\
\hline Genesis & (1) DGB & (1) $2.03 \mathrm{~m} D_{0}$ & (1) Mortar \\
& (2) Parafoil & (2) $325 \mathrm{~m}$ & (2) Pilot Parachute \\
\hline Stardust & (1) DGB & (1) $0.8 \mathrm{~m} D_{0}$ & (1) Mortar \\
& (2) Triconical & (2) $7.3 \mathrm{~m} D_{0}$ & (2) Pilot Parachute \\
\hline Phoenix & DGB & $11.7 \mathrm{~m} D_{0}$ & Mortar \\
\hline Mars Science Laboratory & DGB & $19.7 \mathrm{~m} D_{0}$ & Mortar \\
\hline
\end{tabular}

Notes: Number in parenthesis indicates stage. Later stages deployed by previous stage.

Wind tunnel testing was conducted to finalize the parachute system configuration, and develop the required parachute drag coefficient data for mission analyses. These wind tunnel tests were conducted at Mach numbers from 0.2 to 2.6 in various facilities, with and without the aeroshell upstream of the parachute. Wind tunnel model scale was ten percent. In large part due to the results from the wind tunnel test program, it was decided to increase the suspension line length to $1.7 D_{0}$ (from the $1.0 D_{0}$ used in the technology development flight test programs discussed earlier), and the trailing distance of the parachute to 8.5 aeroshell diameters (measured from the aeroshell maximum diameter to the parachute skirt). These increases in suspension line length and trailing distance increased the parachute's drag coefficient. The final parachute drag coefficient model used for mission design was as shown in figure 7. ${ }^{61}$ This nominal drag curve was derived from wind tunnel test data. Three observations related to this nominal drag curve are particularly interesting: the almost constant drag coefficient for Mach numbers less than 0.6, the large reduction in the drag coefficient at transonic speeds due to interaction with the entry vehicle wake, and the reduction in drag coefficient at Mach numbers above 1.4.

A set of nine low-altitude subsonic development drop tests on engineering models of the parachute system were conducted to verify system operation (i.e., from mortar firing to steady state descent under parachute), and the structural integrity of the parachute. These test were initiated at altitudes of approximately $15 \mathrm{~km}$, by dropping a

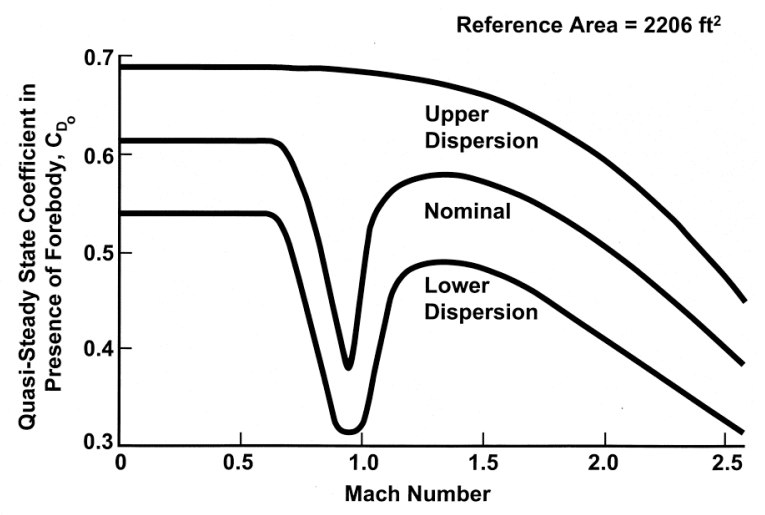

Figure 7. Viking parachute drag coefficient model (redrawn from ref. 61). slender test vehicle from an airplane. As a result of this test program several changes were made to the system, including changes in the parachute disk fabric material, and to the mortar cover. During the last two drop tests the parachute was shown to be capable of sustaining a load 1.3 times the highest expected on Mars.

With the parachute system in its final configuration, four high-altitude flight tests conducted to qualify the system for flight at conditions similar to those that could be encountered on Mars. This was known as the BLDT (Balloon Launched Decelerator Test) program, with each of the flight tests identified by the initials AV and a number (thus, AV-1 was the first test of the series). These tests were conducted using a variant of the balloon/rocket test method discussed earlier and shown in figure 6. All four of these tests included the Viking aeroshell so the wake effects of the aeroshell on the

7

American Institute of Aeronautics and Astronautics 
parachute would be accurately simulated. Of the four tests, three were conducted at supersonic speeds (AV-1, -2, and -4), and one at subsonic speed (AV-3). The supersonic tests Mach number and dynamic pressure at deployment are shown in figure 5. Flight test AV-1 was considered to be a "no test" since problems during the balloon launch caused the test conditions to be exceeded, with subsequent damage to the parachute. The second test, $\mathrm{AV}-2$, was intended to qualify performance at transonic Mach numbers. The purpose of BLDT AV-3 was to qualify the parachute system at subsonic speeds and very low dynamic pressures. For flight test AV-3 no rockets were necessary - the test vehicle was allowed to drop from the balloon until the desired test condition was achieved and the parachute deployment sequence initiated. Finally, flight test AV-4 was a reflight of AV-1, subjecting the parachute to its highest Mach number (2.13) and dynamic pressure (522 Pa). Flight tests AV-2 through -4 were successful, thus qualifying the Viking parachute system for flight.

The final parachute system for the Viking mission consisted of a DGB parachute of $16.2 \mathrm{~m}$ nominal diameter, constructed mainly from Dacron, with a total mass of $44 \mathrm{~kg}$, and deployed by a mortar. ${ }^{61}$ Viking's parachute in its deployed configuration is shown in figure 8 . The design requirements included successful deployment, inflation, and structural integrity for Mach numbers less than or equal to 2.1, at dynamic pressures from 239 to $413 \mathrm{~Pa}$ (the BLDT program intentionally exceeded these limits). Proof of the suitability of the Viking parachute system was obtained from two successful landings on Mars. The performance of the parachute system on Mars is documented in reference 62 .

\section{Pioneer Venus}

The Pioneer Venus mission included four probes that entered the atmosphere of Venus. ${ }^{63}$ Three of these probes were identical and are referred to in the literature as the "Small Probes." Since the Small Probes did not include aerodynamic decelerator systems they will not be discussed further in this survey paper. The fourth probe, referred to in the literature as the "Large Probe," did include an aerodynamic decelerator system, and is thus discussed here. ${ }^{64}$ The aerodynamic decelerator for the Large Probe consisted of a two-stage system. A mortardeployed Ribless Guide Surface pilot parachute of $0.76 \mathrm{~m}$ diameter was used to deploy a $4.94 \mathrm{~m}$ diameter Conical Ribbon parachute. $^{\#}$ Both the pilot and main parachutes were fabricated from Dacron. Given the denser Venusian atmosphere, and the mission requirements, deployment of the pilot parachute was subsonic, at a nominal Mach number of $0.8 .^{4}$ Half a second after mortar firing, the pilot parachute deploys the main parachute. Shortly after main parachute deployment and inflation the heatshield was released. Nineteen minutes later, at an altitude of approximately $47 \mathrm{~km}$ above the surface, the payload and main parachute separated, allowing the payload to free-fall to the surface. The high density of the Venusian atmosphere voided the need for a parachute at lower altitudes.

Initially the main parachute was intended to be of the Ribless Guide Surface type. However, structural failures during drop flight tests of the Ribless Guide Surface main parachute at the design dynamic pressure led to its replacement with a stronger Conical Ribbon main parachute. This change occurred late in the development

\# The available documentation implies that these parachute dimensions are projected diameters. 
program, and is not reflected in some of the earlier published papers on this mission such as reference 65 . Additional testing of the new system at mortar-firing dynamic pressures up to 5,050 $\mathrm{Pa}$ (57 percent above design) showed that both the pilot and main parachutes were capable of sustaining the stresses generated by high dynamic pressure deployment without structural damage. Final qualification of the parachute system was performed through a successful full-scale system drop test.

The difference in operating conditions (i.e., Mach number and dynamic pressure) between the Pioneer Venus parachute system and those developed under the PEPP, SPED, and SHAPE programs (which were focused on Mars) should be noted. Deployment of the Pioneer Venus parachute was initiated subsonically at high dynamic pressure. Parachutes intended for use on Mars initiate deployment supersonically, but at much lower dynamic pressures. There is a factor of five or greater in deployment dynamic pressure between parachute systems intended for operation on Mars and the Pioneer Venus parachute system (see figure 5).

\section{Galileo}

The Galileo probe to Jupiter used a two-stage parachute system. ${ }^{66-70}$ The first stage was a mortar-deployed pilot parachute of $1.14 \mathrm{~m}$ nominal diameter. Almost immediately after its deployment and inflation, the pilot parachute was used to deploy the main parachute. With a nominal diameter of $3.8 \mathrm{~m}$, the main parachute had sufficient drag area when fully inflated to effect positive separation of the heatshield and provide the required descent rate. Both the pilot and main parachutes were of the Conical Ribbon design with canopies and suspension lines fabricated from Dacron. The pilot parachute was intended to be deployed at a nominal Mach number of 0.95 and a dynamic pressure of 5,985 $\mathrm{Pa}$. Because of the short time period $(1.25 \mathrm{~s})$ between the mortar deployment of the pilot parachute and main parachute deployment, the conditions experienced by the main parachute were almost the same as those for the pilot parachute. The high dynamic pressure at deployment for both parachutes indicated that a very robust design should be used. For this strength-critical application a Conical Ribbon parachute was an excellent choice. Note the differences in parachute type (table 2), and deployment conditions (i.e., deployment Mach number and dynamic pressure, figure 5) between the Galileo probe parachutes and those tested under the PEPP, SPED, and SHAPE programs.

The design, development, and qualification test program consisted of three major elements: flight performance verification tests, wind tunnel tests, and high-altitude system drop tests. In the flight performance verification tests the parachute system was mounted on a cylindrical test vehicle and dropped from an F-4 aircraft at overload test conditions ( $q=8,860 \mathrm{~Pa}$ for the pilot parachute and 7,900 $\mathrm{Pa}$ for the main parachute). The first of the flight performance verification test revealed several problems with the parachutes, including undesired pulsations of the pilot parachute and slow inflation of the main canopy. Canopy modifications solved the problems as was demonstrated in a second flight performance verification test. In the high-altitude drop tests the parachute system was deployed behind a simulated Galileo probe. The first test indicated a severe problem with the main parachute inflation - it was erratic and took much longer to reach full inflation than was expected. Wind tunnel tests indicated that the source of the problem was the close proximity of the main parachute to the probe, exacerbated by operation at transonic speeds. An increase in the trailing distance of the main parachute from the original 5.6 to 11 probe diameters, in addition to other system changes, resolved the problems. The effectiveness of these changes was demonstrated in a successful second high-altitude drop test.

The Galileo probe parachute system functioned as intended on Jupiter in 1995, in spite of a 53 second delay in firing the mortar for the pilot parachute. This delay reduced the deployment Mach number, but increased the dynamic pressure to a higher-than-nominal 7,260 $\mathrm{Pa}$. The factors of safety used for the parachute design, which were validated through testing, allowed the Galileo parachutes to survive the more stringent deployment condition on Jupiter.

\section{Lessons Learned}

The initial technology development programs and missions yielded a significant number of lessons learned. It was shown that parachutes could be used successfully at supersonic speeds in low-density atmospheres. However, at Mach numbers greater than 1.5 parachutes experienced stability problems that increased in violence as the Mach number increased. Over this same range of Mach numbers (i.e., $M>1.5$ ), the drag coefficient of these parachutes decreased. The practical upper Mach number range for parachutes was shown to be somewhere between two and three. At Mach numbers above three, other aerodynamic decelerators were shown to be better options. For supersonic applications in low-density atmospheres the DGB parachute was found to be a suitable choice. Conical Ribbon parachutes were found to be preferred canopy type when deployment had to occur at transonic speeds and high dynamic pressures. The parachute trailing distance, especially behind a blunt entry vehicle, was shown to be a key design parameter that needed to be taken into consideration. Mortars were used by all missions to deploy the 
pilot parachute in multi-stage systems, or the main canopy in single-stage systems. This was due to the mortar's ability to deploy the parachute cleanly beyond the recirculating flow region immediately behind the aeroshell.

Inflatable aerodynamic decelerators, both trailing and attached, were found to be useful aerodynamic decelerators. IADs were designed that avoided the stability and low drag problems inherent in parachutes at Mach numbers above two. This implied that IADs could be appropriate aerodynamic decelerator for applications that required deployment at high supersonic and hypersonic conditions. However, since the initial set of planetary exploration missions could be accomplished with parachutes deployed at Mach numbers below 2.1, the development of IADs did not go beyond wind tunnel testing, and no significant flight testing was undertaken to further develop IAD technology.

\section{Present}

This section discusses missions flown from 1990 to the present, and missions currently under development for flight by 2010. Mars, with six missions, was a favorite destination in this time period. However, there were also two sample return missions (Genesis, 2004 and Stardust, 2005), as well as one mission to Titan (Huygens, 2005).

\section{A. Missions to Mars - 1997 to 2010}

A renewed interest in the exploration of Mars has led to four missions being flown between 1997 and 2004, and two more to be flown before the end of this decade. Because of their similarities to Viking, all of these missions have made extensive use of Viking parachute heritage for their own parachute systems. ${ }^{71}$ In this section all of these missions are discussed - including those that did not succeed. Valuable lessons can be learned from all of them.

\section{Mars Pathfinder}

After a 20-year gap since the Viking mission, the Mars Pathfinder (MPF) mission revitalized the exploration of Mars. Due to costs constraints it was decided to use as much of the Viking heritage technologies as possible. Among these technologies was the aerodynamic decelerator. Mars Pathfinder used a mortar-deployed single-stage DGB parachute of $12.7 \mathrm{~m}$ nominal diameter. ${ }^{72}$ The airbag landing system used by MPF placed stability requirements on the parachute that could not be met with a canopy of the geometry flown by Viking. Thus, the Viking DGB parachute was modified to increase its stability. The principal modification made to improve stability was an increase in the length of the band. This change had been shown to increase the stability of DGB parachutes in wind tunnel tests. Qualification of the MPF parachute was conducted through low-altitude flight tests in addition to making extensive use of heritage data from previous research programs and the Viking mission. Parachute deployment on Mars took place at a Mach number of 1.71 and a dynamic pressure of $588 \mathrm{~Pa}^{73}$ The MPF parachute performed as required, placing its payload safely on the surface of Mars on July 4, 1997. This successful landing indicated that a planetary parachute system could be designed without conducting a high-altitude (and high-cost) supersonic flight test program by judicious use of heritage designs and data. Flight performance of the MPF parachute was reconstructed by Witkowski ${ }^{73}$, and Desai et al. ${ }^{74}$.

\section{Mars Polar Lander}

The Mars Polar Lander (MPL) ${ }^{75}$ used a flight spare parachute system from MPF. Thus, it was identical to that described above. Parachute deployment initiation is estimated to have occurred at a Mach number between 1.7 and 1.85 , at a corresponding dynamic pressure between 440 and $564 \mathrm{~Pa}^{76}$ The parachute system was qualified mainly by heritage using data from the MPF qualification test program. All attempts to contact the spacecraft after EDL were unsuccessful - MPL was lost. The JPL special review board convened to investigate the loss concluded that the most likely cause of failure was premature shutdown of the descent engines. It was the board's judgment that the parachute system was unlikely to have been source of failure.

\section{Mars Exploration Rovers}

In January 2004 two Mars Exploration Rovers (MER A and B), successfully landed on the surface of Mars. ${ }^{77,78}$ The MER EDL system was initially intended to be a built-to-print (with minor modifications) of the MPF EDL system. However, as the design progressed the entry mass increased from $585 \mathrm{~kg}$ for MPF to $830 \mathrm{~kg}$ for MER. Thus, the final MER EDL system design had little in common with the MPF EDL system other than the general system architecture and the aeroshell external dimensions.

The MER parachute system consisted of a single-stage mortar-deployed DGB parachute of $14.1 \mathrm{~m}$ in diameter. ${ }^{79,80}$ As with the MPF DGB parachute, the MER DGB parachute had an elongated band (as compared to the Viking DGB parachute geometry) to enhance the parachute's stability - a key requirement of MPF's and MER's EDL architecture. Deployment of the parachute was initiated at a dynamic pressure of approximately $729 \mathrm{~Pa}$ for 
MER A and 765 Pa for MER B, with corresponding Mach numbers of approximately 1.8 and 1.9, respectively. The dynamic pressure at deployment was significantly higher than that experienced by Viking and MPF.

Design, development, and qualification ${ }^{81}$ of the MER parachute system was conducted through a series of ground tests, ${ }^{82}$ sub-scale wind tunnel tests, ${ }^{83}$ low-altitude drop tests, ${ }^{84,85}$ and full-scale wind tunnel tests. ${ }^{86,87}$ Particularly interesting in these series of tests was the full-scale structural qualification test program conducted in the NASA Ames National Full-Scale Aerodynamics Complex. Testing in this facility allowed improved control of the test conditions and opening loads (as compared to low-altitude drop testing), in addition to providing the desired infinite mass inflation condition. In concert with these test programs, significant efforts were expended in modeling the parachute system dynamics. ${ }^{88,89}$ As with the other missions to Mars in this time period, MER made extensive use of the Viking heritage in the design and qualification of its parachute system.

\section{Beagle 2}

Beagle 2 was a joint United Kingdom/European Space Agency program to place a small lander $(69 \mathrm{~kg}$ entry mass $)^{90}$ on the surface of Mars. This spacecraft used a two-stage parachute system. A small DGB drogue parachute was to be mortar-deployed at a Mach number of approximately 1.5. Once the lander decelerated to a Mach number between 0.4 and 0.6, the drogue parachute was to deploy a Ringsail main parachute of $10.0 \mathrm{~m}$ in nominal diameter. $^{91-93}$ An interesting aspect of this mission was the use of a Ringsail main parachute, instead of the commonly used DGB canopy. This was done to take advantage of the greater drag coefficient provided by Ringsail canopies as compared to DGB canopies. Key elements of the design, development, and qualification test program included low altitude tests for drag, stability, and structural strength, ground vehicle tow tests for structural strength, and high-speed main parachute extraction tests. The Mars Express spacecraft released Beagle 2 on December 19, 2003. Entry onto Mars occurred on December 25, 2003. Contact was never established with Beagle 2, and the mission was considered lost. A Commission of Inquiry was constituted to investigate the loss. ${ }^{90}$ Although the available information was insufficient to firmly establish a root cause for the loss, several possibilities were identified. Two of these possibilities involved the parachute: re-contact between the back cover (suspended under the drogue parachute) and the main parachute after separation, and rebounding of the air-bag encapsulated lander and the main parachute. The failure of Beagle 2 underscored the need for ample margins in all aspects of planetary parachute system design.

\section{Phoenix}

The Phoenix lander is a sister ship to the Mars Polar Lander discussed above. It was supposed to have been flown in 2001, but failure of the Mars Polar Lander in 1999 forced it into storage - to be revived as the Phoenix mission scheduled for landing on Mars in 2008. The single-stage parachute system consists of a mortar-deployed DGB parachute of $11.73 \mathrm{~m}$ nominal diameter. This parachute will use the Viking DGB parachute canopy geometry. Nominal parachute deployment is intended to occur at a dynamic pressure of $430 \mathrm{~Pa}$ and a Mach number of 1.3. Parachute system qualification will take place through ground testing, and low-altitude drop testing for structural qualification of the parachute. As with other missions, Viking heritage will be used to show compliance with some of the parachute system requirements.

\section{Mars Science Laboratory}

With an entry mass of approximately $2,700 \mathrm{~kg}$, and an aeroshell of $4.5 \mathrm{~m}$ in diameter, the Mars Science Laboratory (MSL) will be the largest lander mission yet flown to Mars when it arrives in 2010. ${ }^{94}$ Its aerodynamic decelerator consists of a single-state parachute system: a mortar-deployed DGB parachute of $19.7 \mathrm{~m}$ nominal diameter. Nominal parachute deployment is intended to occur at a dynamic pressure of $525 \mathrm{~Pa}$ and a Mach number of 2.0. The parachute canopy geometry is of the Viking type. System qualification is planned to take place through ground testing, and wind tunnel testing for parachute structural qualification as was done for MER. Again, Viking heritage will be used to shown compliance with some of the parachute system requirements. One interesting aspect of the MSL parachute system design, development, and qualification is its use of CFD and FSI to provide supporting insights and data on the parachute. To our knowledge this is the first planetary mission to use CFD and FSI in this way.

\section{B. Huygens}

The Huygens probe, part of the Cassini mission to Saturn, was designed to investigate the atmosphere of Titan, Saturn's largest moon. The passage of the probe through the atmosphere was controlled by the Descent Control Sub-System (DCSS), which comprised three parachutes and associated mechanisms. The Cassini-Huygens spacecraft was launched in October 1997. 
Huygens had a mass of $320 \mathrm{~kg}$ at entry and a landed mass of $197 \mathrm{~kg}$. The parachute sequence for the probe is shown in figure 9. It starts at Mach number of 1.49, $156 \mathrm{~km}$ above the surface of Titan (figure 9a). At this point, 271 seconds after first encountering the atmosphere, the probe is still encased in its protective aeroshell. The first function of the parachute system is to remove the backshell using a mortar-deployed, $2.59 \mathrm{~m}$ DGB parachute of a design geometrically similar to that used on Viking (figure 9b). As the pilot parachute separates the backshell from the probe (figure 9c), a second, $8.31 \mathrm{~m}$ parachute is deployed by a bridle. This parachute, a DGB of a slightly different design, provides stability as the probe decelerates through the transonic regime (figure 9d) and sufficient drag to ensure separation of the heatshield from the probe when it is released 32.5 seconds into the sequence (figure 9e). Once the aeroshell has separated from the probe, the science instruments start to take data as the probe descends through the upper atmosphere (figure 9f). If the probe were to remain in this configuration the
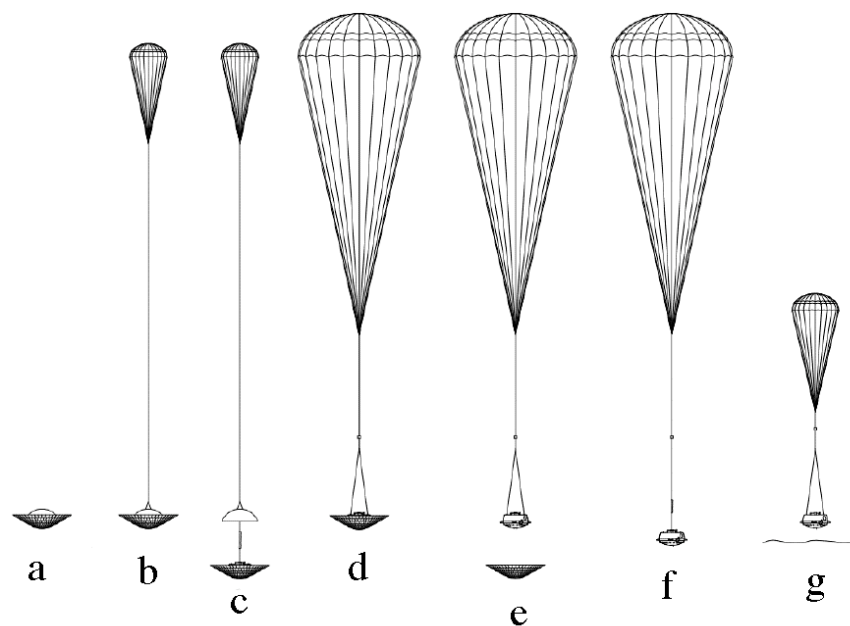

Figure 9. Huygens probe parachute sequence.

probe descent to the surface would take over 5 hours. Since battery life for the probe is only guaranteed for a little over 2.5 hours, the main parachute is released 15 minutes after the start of the descent sequence and in turn deploys a $3.03 \mathrm{~m}$ stabilizing drogue (figure $9 \mathrm{~g}$ ) for the descent to the surface. The sequence has been documented in detail in reference 95. The mass of the flight Huygens Descent Control Sub-System, including all mechanisms and containers, was $11.9 \mathrm{~kg}$.

After trade studies the DGB was selected for all stages, based on Viking heritage. Initially all parachutes had scaled Viking geometry with a reduced number of gores. A very robust margin policy was adopted for the Huygens parachutes to allow for uncertainties in operational conditions and material degradation during the voyage.

Unlike Viking, probe stability during descent was critical for Huygens. The probe attitude had to be maintained at less than 10 degrees to the vertical in order to avoid loss of up-link. Pitch rate had to be less than $6 \mathrm{deg} / \mathrm{s}$ to prevent blurring of the images produced by the onboard camera. A very stable parachute was therefore mandatory. The aerodynamic stability of the DGB design is provided by the geometric porosity of the gap and the intrinsic porosity of the parachute material. In low Earth atmosphere stability is good. During development of the parachutes an analysis of the effects of the Titan atmosphere on the porosity characteristics revealed that the intrinsic porosity of the material became very low at high altitudes on Titan, substantially reducing the stability of the parachute. ${ }^{96}$ To compensate a new DGB gore pattern was adopted with increased geometric porosity for the main parachute and stabilizing drogue stages. The stability of the DGB parachutes used on MER and Mars Pathfinder was enhanced in a different manner, by extending the band length.

The Huygens parachute system was subjected to an extensive test campaign ${ }^{97,98}$ to verify deployment, inflation, aerodynamic performance and structural integrity. Wind tunnel testing in the $4.0 \mathrm{~m}$ by $2.7 \mathrm{~m}$ subsonic tunnel at the Defence Research Agency, Bedford, UK and the $4.9 \mathrm{~m}$ by $4.9 \mathrm{~m}$ transonic tunnel at Arnold Engineering Development Center in Tennessee yielded a comprehensive aerodynamic database for both the Viking DGB configuration and the increased geometric porosity Huygens configuration over the range Mach 0.2 to Mach 1.5. Full scale drop testing, using a specially developed instrumented vehicle, was used to verify full scale subsonic performance and structural strength. ${ }^{99}$ This included a 25 percent overload test. The full sequence of operation of the parachute system, from initiation of the mortar through to ground impact, was finally qualified by means of a high-altitude test. In this test a probe model was dropped from a balloon flying at $40 \mathrm{~km}$ altitude. Mach number for the first two parachute stages could not be matched but dynamic pressure was as predicted for the mission. ${ }^{100,101}$

During the 7-year voyage from Earth to Titan the probe trajectory was changed as a result of improved knowledge of the atmosphere, revised arrival conditions and a new analysis of the sequence detection algorithm. As a result the maximum deployment Mach number increased from Mach 1.76 to Mach 2.0 and the dynamic pressure range increased from 287-440 $\mathrm{Pa}$ to 240-500 $\mathrm{Pa}$. A revalidation of the Huygens parachute system was therefore necessary for the more severe operational range. The system was shown still to have positive margins throughout, a vindication of the robust margin policy. ${ }^{102}$ Final demonstration of the design was achieved when the probe successfully landed on the surface of Titan on January 14, 2005. 


\section{Sample Return Missions: Genesis and Stardust}

Two sample return missions were flown in the time period encompassed within this section: Genesis and Stardust. Both of these missions used parachutes during the final phase of their EDL sequences.

\section{Genesis}

Genesis was a mission intended to return samples of solar wind to Earth. ${ }^{103}$ The entry system consisted of a blunt-body aeroshell with a diameter of $1.52 \mathrm{~m}$ and an entry mass of $205 \mathrm{~kg}$. Genesis' aerodynamic decelerator was a two-stage system. The first stage consisted of a mortar-deployed DGB drogue parachute of $2.03 \mathrm{~m}$ nominal diameter. This drogue parachute was to be deployed at supersonic speed for the purpose of stabilizing the aeroshell during the transonic phase and to slow the vehicle to subsonic speeds. Once the aeroshell had decelerated to subsonic speed, the drogue parachute was to be used to deploy a $325 \mathrm{~m}^{2}$ nominal area parafoil second stage. ${ }^{104}$ Before the sample return capsule was to land, a helicopter was to capture the descending parafoil and sample return capsule to avoid the accelerations associated with landing impact. Design, development, and qualification of the Genesis parachute system was performed through ground and low-altitude flight testing, in addition to using heritage data from previous research efforts and missions. Genesis returned to Earth on September 8, 2004. Unfortunately the drogue parachute was not deployed, and Genesis crashed onto the Utah Test and Training Range (UTTR). The Mishap Investigation Board convened to investigate the failure determined that the root cause was the incorrect installation of the G-switch sensor used to command the mortar firing. ${ }^{105}$ Because of this incorrect installation the command to fire the mortar was never issued.

\section{Stardust}

Stardust was a mission intended to return comet and interstellar dust particles to Earth. ${ }^{106}$ The entry system consisted of a $0.8 \mathrm{~m}$ diameter blunt-body aeroshell with an entry mass of $46 \mathrm{~kg}$. Stardust's aerodynamic decelerator was a two-stage system. The first stage consisted of a mortar-deployed DGB drogue parachute of $0.83 \mathrm{~m}$ nominal diameter. This drogue parachute was deployed at a Mach number of approximately 1.4 for the purpose of stabilizing the aeroshell during the transonic phase and to slow the entry vehicle to subsonic speeds. Once the aeroshell had decelerated to a Mach number of approximately 0.15 , the drogue parachute was used to deploy a $7.3 \mathrm{~m}$ nominal diameter Triconical main parachute. This main parachute was sized to reduce the landing speed to $4.4 \mathrm{~m} / \mathrm{s}$. Design, development, and qualification of the Stardust parachute system was performed through ground and lowaltitude flight testing, in addition to using data from the Huygens mission as heritage. ${ }^{107}$ Stardust successfully landed at the UTTR on January 15, 2006.

\section{Lessons Learned}

All missions in this time period used a mortar-deployed DGB parachute for at least one, if not all, of its stages. The DGB parachute has turned out to be a versatile canopy design for planetary missions. It has been used in a variety of nominal diameters from less than one to almost twenty meters, and modified to yield the stability required by specific missions. Judicious use of the Viking heritage, especially with regards to the supersonic flight test data, has allowed for parachute systems to be designed, built, and qualified without repeating the expensive high-altitude supersonic flight test program conducted by the Viking mission. However, this success comes with the limitation of staying within this heritage - an ill-defined boundary. Wind tunnel testing, both sub-scale and full-scale, proved again to be a useful tool in the design, development, and qualification of parachute systems. Lessons to be learned from failed missions included the importance of triggering devices and switches (i.e., MPL and Genesis), and the importance of conservatism and margin in the design (Beagle 2).

\section{Future}

As we look to future missions, three technologies stand out as having the potential to significantly improve aerodynamic decelerators: Computational Fluid Dynamics (CFD) and Fluid-Structures Interaction Analyses (FSI), large subsonic parachutes, and inflatable aerodynamic decelerators. These technologies are discussed in this section.

\section{A. Computational Fluid Dynamics and Fluid-Structures Interaction Analyses}

The solution of the coupled flow around an inflating, decelerating parachute structure would provide improved understanding of parachute aerodynamic performance and improved prediction of loads and stresses in the parachute structure, leading to more efficient designs. Moreover, fully validated analytical methods could contribute to the verification process, reducing development costs. 
The analysis of parachutes is, however, difficult. It necessitates the solution of unsteady, separated compressible flows about a flexible, porous body with non-uniform upstream flow conditions. In supersonic flow the wake of the payload interacts strongly with the stagnant region inside the parachute. Nonetheless there have been many efforts to apply computational fluid dynamics and fluid structure interaction to parachutes. A useful summary of work up to 1995 is provided in reference 108 .

Most early studies were based on gridless, Vortex Element Methods (VEM). ${ }^{109-111}$ This approach represented the parachute canopy with bound vortex elements or sheets and allowed the computation of the inviscid, incompressible flow around parachute shaped bodies, added masses and pressure distributions. VEM methods were refined to model viscous flow and predict the drag of rigid parachute shapes during steady and unsteady motion. ${ }^{12-116}$ The coupling of VEM fluid codes to structural codes has also allowed the modeling of parachute inflation. ${ }^{117-119}$ Chatzikonstantinou ${ }^{120-122}$ reports the use of a VEM code coupled to a structural code to model ram-air parachutes. VEM methods are powerful and computer efficient. Vortex elements need only be placed in regions where there is vorticity. For a divergence free flow field the flow is completely defined by the vorticity. Moreover, there is no numerical dissipation associated with the transport of vorticity. Separation has to be handled by prescription of a separation location or integral boundary layer calculation. This method has only been used to date for incompressible flows.

Early use of 3-D Navier-Stokes based CFD codes for predicting the flow over rigid parachute shapes are reported in references 123 and 124. Strickland ${ }^{108}$ reports loose coupling of CFD to a structural code model a cross parachute. Sahu ${ }^{125}$ describes the loose coupling a 3-D incompressible Navier-Stokes code to the CALA parachute structural code for a flat circular parachute in steady descent. References 126 through 129 describe the extensive US Army efforts to model fluid structure interaction using the stabilized space-time formulation of the time dependent Navier-Stokes equations coupled to a finite element code. These efforts were applied to a man carrying parachutes and cargo parachute clusters, and gliding parachutes during descent.

Using conventional grid based CFD, to properly resolve the flow it is necessary to include a significant proportion of the wake region in the calculation. In order to resolve the wake structure and reduce numerical dissipation it must be finely gridded. Moreover, to model a flexible body re-gridding is required at every time step, significantly increasing computational costs. Conventional CFD is therefore best suited to modeling the flow around rigid parachute shapes.

Early use of the Arbitrary Lagrangian-Eulerian (ALE) formulation of the Navier-Stokes equations for modeling decelerators is described in references 130 through 132. ALE is a technique for modeling material deformation with a discretised mesh by allowing the material to flow through the mesh to varying extent. In the zero-mass flow condition, the mesh deforms with the material as loads are applied to the structure; this is the Lagrangian method typically used for finite element modeling. In the total mass flow conditions, the mesh remains fixed in space and the code tracks the deformation and movement of the material through the mesh; this is the Eulerian method as typified by CFD solvers. Moreover, a Lagrangian, fixed mesh body can be allowed to move through and interact with surrounding Eulerian material. By defining appropriate material properties and equations of state for the Eulerian material, full coupling between the fluid and the flexible parachute can be simulated.

The early studies modeled simple configurations: disks, hemispherical cups and rigid parachute models. This technique recently advanced rapidly with the introduction of an ALE solver into the explicit finite element code LS-DYNA, allowing fully coupled fluid structure interaction simulation for compressible flows. Taylor ${ }^{133}$ reports the use of the code to study the post inflation collapse phenomenon and Tutt $^{134}$ discusses modeling of parachute inflation. Simulation of the Huygens parachute system in the supersonic regime was presented by Lingard. ${ }^{135}$ This work for the first time revealed the complex interaction between the forebody wake and the parachute bow shock as shown in figure 10 .

Coupled FSI based on the ALE methodology promises rapid acceleration of the understanding of parachute performance. Simulation of parachute inflation is feasible in the near future and, since the fluid code is coupled to a detailed structural model, detailed unsteady stress prediction is available. This tool is currently being used to support the NASA Mars Science Laboratory and ESA ExoMars parachute development programs. 


\section{B. Large Subsonic Parachutes}

Trade studies for Mars missions significantly larger than MSL, for example those with entry mass between 4,000 and $5,000 \mathrm{~kg}$, indicate that parachutes with large subsonic drag areas may be required. ${ }^{136}$ Such parachutes may be part of a two-stage system, with the first stage being an improved supersonic parachute based on current DGB technology, or an inflatable supersonic decelerator capable of deploying above Mach 3.

For a single-canopy Ringsail parachute system with entry mass in the 4,000 to $5,000 \mathrm{~kg}$ range the parachute nominal diameter is estimated to be between 43 and $50 \mathrm{~m}$. Although Ringsail parachutes with nominal diameter up to $58 \mathrm{~m}$ have been successfully tested at subsonic speed and low altitude on Earth, on Mars these parachutes will be operating in a low-density environment at Mach numbers up to 0.8 . A recent NASA effort ${ }^{137,138}$ to develop a $33.5 \mathrm{~m}$ nominal diameter Ringsail parachute had some success, but difficulties with pilot parachute deployment of such a large canopy in a low-density atmosphere were not fully resolved before the program was terminated. A clusteredcanopy design with multiple smaller canopies may solve some of the deployment problems by shortening the inflation time. However, canopy clusters exhibit their own unique problems such as asynchronous inflation of the canopies. Development of large subsonic parachutes for Mars missions remains as a project for the future - one that will require significant testing before all problems are resolved, and confidence in the system is raised to the level required by flight projects.

\section{Inflatable Aerodynamic Decelerators}

To land large payloads on Mars at altitudes above the Mars Orbiter Laser Altimeter (MOLA) datum with the constraints of current launch vehicle fairing dimensions necessitates parachute deployment at Mach numbers above the currently qualified maximum of Mach 2.1. ${ }^{71}$ The DGB parachute has been used for all Mars missions to date, and has been tested successfully to Mach 2.7. However, as has been previously discussed, increasingly violent inflation instabilities and reductions in drag coefficient above Mach 1.5 limit the useful Mach number operational range of parachutes to somewhere between Mach 2 and 3. These problems with parachutes have renewed interest in IADs.

The Hypercone, ${ }^{139}$ shown in figure 11 , is an attached inflatable aerodynamic decelerator designed to provide deceleration and stabilization in the Martian atmosphere from approximately Mach 4 to subsonic conditions. It comprises an inflated torus supporting a conical fabric membrane forward section. The Hypercone is fully flexible and can be packed like

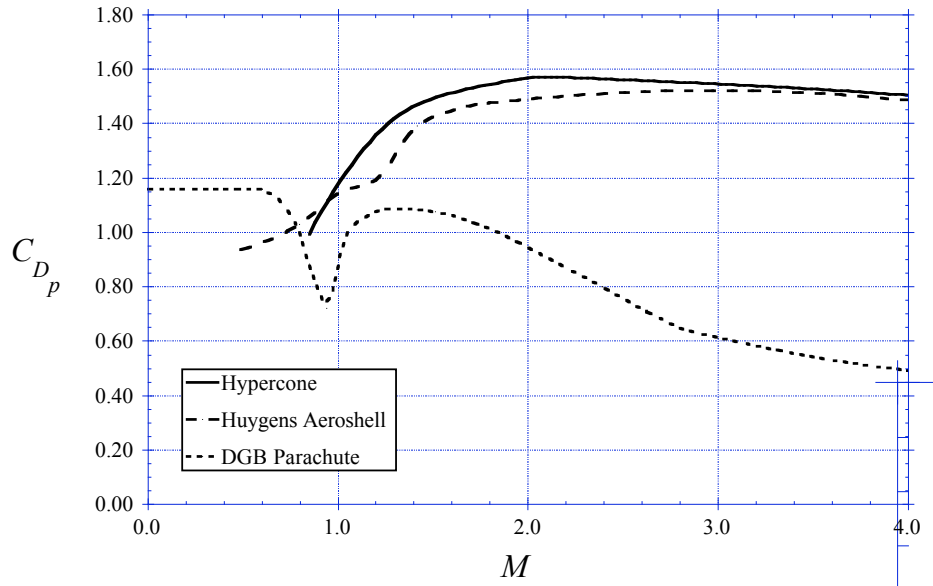

Figure 12. Comparison between the Hypercone IAD, rigid aeroshell, and parachute drag performance. All drag coefficients are based on the projected frontal area.

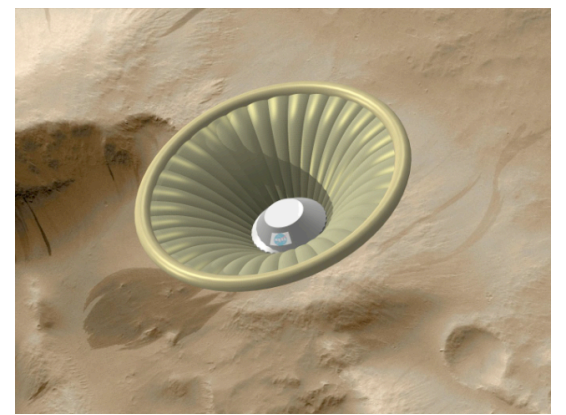

Figure 11. Hypercone IAD concept.

a parachute. It is deployed directly attached to the lander. The aerodynamic drag of the Hypercone increases with Mach number in the transonic and low supersonic Mach number range in a manner similar to an aeroshell, whereas the drag of a parachute reduces at low supersonic Mach numbers as shown in figure 12. The Hypercone therefore can provide an efficient bridging decelerator between the aeroshell and a subsonic parachute.

Studies comprising trajectory, aerodynamic, structural and stability analyses, showed that the Hypercone is a viable device that provides mass savings and risk reduction over a conventional parachute system and can contribute to achieving larger lander mass. A $14 \mathrm{~m}$ diameter Hypercone with a mass fraction of only $3.8 \%$ was shown to facilitate the delivery of a $4,000 \mathrm{~kg}$ lander to a site $2.5 \mathrm{~km}$ above the MOLA reference surface. 139 


\section{Concluding Remarks}

The aerodynamic decelerator technology developed by previous generations of researchers and engineers have served us well for several decades. In large part the usefulness of their work was not only in their technical accomplishments, but also in the fact that they documented their efforts - both successful and unsuccessful. These heritage data has allowed us to design new systems without having to completely retrace their path. However, these technologies are reaching their performance limits. Future planetary exploration missions will need new developments to provide the needed drag area and Mach number operational range. ${ }^{71}$ New-technology larger parachutes may provide the required drag area, while inflatable aerodynamic decelerators may allow deployment at higher Mach numbers. In the development of these new technologies, computational fluid dynamics and fluidstructures interaction analyses will be of value in the design and analysis of aerodynamic decelerators, and in the definition of cost-effective qualification test programs. However, just as in the past, an investment will need to be made to develop these new technologies. A decade of experimentation led to the development of the Viking parachute system - at that time a new technology. To support future missions the technology development must start well in advance.

\section{References}

${ }^{1}$ Perminov, V. G., "The Difficult Road to Mars - A Brief History of Mars Exploration in the Soviet Union," NASA Monographs in Aerospace History Number 15, NASA NP-1999-06-251-HQ, 1999.

${ }^{2}$ Ravnitzky, M. J., Patel, S. N., and Lawrence, R. A., "To Fall from Space: Parachutes and the Space Program,” AIAA Paper 89-0926, 1989.

${ }^{3}$ Knacke, T. W., Parachute Recovery Systems Design Manual, Para Publishing, Santa Barbara, California, 1992. (Also available as U.S. Naval Weapons Center Report NWC-TP-6575.)

${ }^{4}$ Ewing, E. G., Bixby, H. W., and Knacke, T. W., "Recovery System Design Guide," AFFDL-TR-78-151, 1978.

${ }^{5}$ Worth, R. N., "Descent and Landing Systems for Unmanned Mars Entry," Journal of Spacecraft and Rockets, Vol. 3, No. 12, 1966, pp. 1744-1748.

${ }^{6}$ Gillis, C. L., "Deployable Aerodynamic Decelerators for Space Missions," Journal of Spacecraft and Rockets, Vol. 6, No. 8, 1969 , pp. 885-890.

${ }^{7}$ Anon., "Titan/Mars Hard Lander, Volume 1: 1400 lb Capsule System Design Study,” NASA CR-66727-1, 1969.

${ }^{8}$ Maynard, J. D., "Aerodynamic Characteristics of Parachutes at Mach Numbers from 1.6 to 3,” NASA TN D-752, 1961.

${ }^{9}$ Charczenko, N., "Wind-Tunnel Investigation of Drag and Stability of Parachutes at Supersonic Speeds," NASA TM X-991, 1964.

${ }^{10}$ Mayhue, R. J. and Bobbitt, P. J., "Drag Characteristics of a Disk-Gap-Band Parachute with a Nominal Diameter of 1.65 Meters at Mach Numbers from 2.0 to 3.0," NASA TN D-6894, 1972.

${ }^{11}$ Charczenko, N. and McShera, T., "Aerodynamic Characteristics of Towed Cones Used as Decelerators at Mach Numbers from 1.57 to 4.65," NASA TN D-994, 1961.

${ }^{12}$ Charczenko, N., "Aerodynamic Characteristics of Towed Spheres, Conical Rings, and Cones Used as Decelerators at Mach Numbers from 1.57 to 4.65 ," NASA TN D-1789, 1963.

${ }^{13}$ McShera, J. T., "Aerodynamic Drag and Stability Characteristics of Towed Inflatable Decelerators at Supersonic Speeds," NASA TN D-1601, 1963.

${ }^{14}$ Barton, R. R., "Development of Attached Inflatable Decelerators for Supersonic Applications," NASA CR-66613, 1968.

${ }^{15}$ Mikulas Jr., M. M. and Bohon, H. L., "Development Status of Attached Inflatable Decelerators," Journal of Spacecraft and Rockets, Vol. 6, No. 6, 1969, pp. 654-660.

${ }^{16}$ Bohon, H. L. and Miserentino, H. L., "Deployment and Performance Characteristics of 5-Foot-Diameter (1.5 m) Attached Inflatable Decelerators from Mach Number 2.2 to 4.4," NASA TN D-5840, 1970.

${ }^{17}$ Bohon, H. L., Sawyer, J. W., and Miserentino, R., "Deployment and Performance Characteristics of 1.5-Meter Supersonic Attached Inflatable Decelerators," NASA TN D-7550, 1974.

${ }^{18}$ Boettcher, E. W., "Planetary Entry Parachute Program, Cross Parachute Engineering Design Report," NASA CR-66590, 1967.

${ }^{19}$ Eckstrom, C. V. and Murrow, H. N., "Flight Test of a 40-Foot-Nominal-Diameter Modified Ringsail Parachute Deployed at a Mach Number of 1.64 and a Dynamic Pressure of 9.1 Pounds per Square Foot," NASA TM X-1484, 1967.

${ }^{20}$ Eckstrom, C. V. and Preisser, J. S., "Flight Test of a 30-Foot-Nominal-Diameter Disk-Gap-Band Parachute Deployed at a Mach Number of 1.56 and a Dynamic Pressure of 11.4 Pounds per Square Foot," NASA TM X-1451, 1967.

${ }^{21}$ Darnell, W. L., Henning, A. B., and Lundstrom, R. R., "Flight Test of a 15-Foot-Diameter (4.6 Meter) $120^{\circ}$ Conical Spacecraft Simulating Parachute Deployment in a Mars Atmosphere," NASA TN D-4266, 1967.

${ }^{22}$ Lemke, R. A., "Final Report: 40 Ft DGB parachute,” NASA CR-66587, 1967.

${ }^{23}$ Lemke, R. A., Moroney, R. D., Neuhaus, T. J., and Niccum, R. J., "Design Report, 65 Foot Diameter D-G-B Parachute, Planetary Entry Parachute Program,"NASA-CR-66589, 1967.

${ }^{24}$ McFall, J. C. and Murrow Jr., H. N., "Parachute Testing at Altitudes Between 30 and 90 Kilometers," Journal of Spacecraft and Rockets, Vol. 4, June, 1967, pp. 796-798. 
${ }^{25}$ Preisser, J. S. and Eckstrom, C. V., "Flight Test of a 31.2-Foot-Diameter Modified Ringsail Parachute Deployed at a Mach Number of 1.39 and a Dynamic Pressure of 11.0 Pounds per Square Foot," NASA TM X-1414, 1967.

${ }^{26}$ Stone, F. J., "Final Technical Report, 55-ft-D 0 Ringsail Parachute, Planetary Entry Parachute Program," NASA CR-66588, 1967.

${ }^{27}$ Whitlock, C. H., Bendura, R. J., and Coltrane, L. C., "Performance of a 26-Meter-Diameter Ringsail Parachute in a Simulated Martian Environment," NASA TM X-1356, 1967.

${ }^{28}$ Bendura, R. J., Huckins III, E. K., and Coltrane, L. C., "Performance of a 19.7-Meter-Diameter Disk-Gap-Band Parachute in a Simulated Martian Environment," NASA TM X-1499, 1968.

${ }^{29}$ Eckstrom, C. V. and Preisser, J. S., "Flight Test of a 40-Foot-Nominal-Diameter Disk-Gap-Band Parachute Deployed at a Mach Number of 2.72 and a Dynamic Pressure of 9.7 Pounds per Square Foot,” NASA TM X-1623, 1968.

${ }^{30}$ Gillis, C. L. and Bendura, R. J., "Full-Scale Simulation of Parachute Deployment Environment in the Atmosphere of Mars," Proceedings of the $14^{\text {th }}$ Annual Technical Meeting, Institute of Environmental Sciences, 1968, pp. 469-475.

${ }^{31}$ Lundstrom, R. R., Darnell, W. L., and Coltrane, L. C., "Performance of a 16.6-Meter-Diameter Cross Parachute in a Simulated Martian Environment," NASA TM X-1543, 1968.

${ }^{32}$ Lundstrom, R. R., Darnell, W. L., and Henning, A. B., "A Method for Making Large-Scale Decelerator Tests in a Simulated Mars Environment," AIAA Paper 68-241, 1968.

${ }^{33}$ Preisser, J. S. and Eckstrom, C. V., "Flight Test of a 30-Foot-Nominal-Diameter Cross Parachute Deployed at a Mach Number of 1.57 and a Dynamic Pressure of 9.7 Pounds per Square Foot," NASA TM X-1542, 1968.

${ }^{34}$ Preisser, J. S. and Eckstrom, C. V., "Flight Test of a 40-Foot-Nominal-Diameter Disk-Gap-Band Parachute Deployed at a Mach Number of 1.91 and a Dynamic Pressure of 11.6 Pounds per Square Foot," NASA TM X-1575, 1968.

${ }^{35}$ Whitlock, C. H., Henning, A. B., and Coltrane, L. C., "Performance of a 16.6-Meter-Diameter Modified Ringsail Parachute in a Simulated Martian Environment,"NASA TM X-1500, 1968.

${ }^{36}$ Murrow, H. N. and McFall Jr., J. C., "Some Test Results from the NASA Planetary Entry Parachute Program," Journal of Spacecraft and Rockets, Vol. 6, No. 5, 1969, pp. 621-623.

${ }^{37}$ Whitlock, C. H. and Bendura, R. J., "Inflation and Performance of Three Parachute Configurations from Supersonic Flight Tests in a Low-Density Environment," NASA TN D-5296, 1969.

${ }^{38}$ Eckstrom, C. V., "High-Altitude Flight Test of a 40-Foot-Diameter (12.2-meter) Ringsail Parachute at a Deployment Mach Number of 2.95," NASA TN D-5796, 1970.

${ }^{39}$ Eckstrom, C. V., "Flight Test of a 40-Foot-Nominal-Diameter Disk-Gap-Band Parachute Deployed at a Mach Number of 3.31 and a Dynamic Pressure of 10.6 Pounds per Square Foot," NASA TM X-1924, 1970.

${ }^{40}$ Murrow, H. N. and Eckstrom, C. V., "Low- and High-Altitude Tests of Parachutes Designed for Use in Low-Density Atmospheres," AIAA Paper 70-1164, 1970.

${ }^{41}$ Eckstrom, C. V. and Murrow, H. N., "Flight Tests of Cross, Modified Ringsail, and Disk-Gap-Band Parachutes from a Deployment Altitude of 3.05 km (10 $000 \mathrm{ft})$," NASA TM X-2221, 1971.

${ }^{42}$ Preisser, J. S. and Grow, R. B., "High-Altitude Flight Test of a Reefed 12.2-Meter-Diameter Disk-Gap-Band Parachute with Deployment at a Mach Number of 2.58," NASA TN D-6469, 1971.

${ }^{43}$ Eckstrom, C. V. and Branscome, D. R., "High-Altitude Flight Test of a Disk-Gap-Band Parachute Deployed Behind a Bluff Body at a Mach Number of 2.69," NASA TM X-2671, 1972.

${ }^{44}$ Henning, A. B. and Lundstrom, R. R., "Flight Test of an Erectable Spacecraft Used for Decelerator Testing at Simulated Mars Entry Conditions," NASA TN D-6910, 1972.

${ }^{45}$ Lau, R. A. and Hussong, J. C., “The Viking Mars Lander Decelerator System,” AIAA Paper 70-1162, 1970.

${ }^{46}$ Gillis, C. L., "The Viking Decelerator System - An Overview," AIAA Paper 73-442, 1973.

${ }^{47}$ Jaremenko, I., Steinberg, S., and Faye-Petersen, R., "Scale Model Test Results of the Viking Parachute System at Mach Numbers from 0.1 through 2.6," NASA CR-149377, 1971.

${ }^{48}$ Reichenau, D. E. A., "Aerodynamic Characteristics of Disk-Gap-Band Parachutes in the Wake of Viking Entry Forebodies at Mach Numbers from 0.2 to 2.6," AEDC-TR-72-78, 1972.

${ }^{49}$ Steinberg, S., Siemers III, P. M., and Slayman, R. G., "Development of the Viking Parachute Configuration by WindTunnel Investigation," Journal of Spacecraft and Rockets, Vol. 11, No. 2, 1974, pp. 101-107.

${ }^{50}$ Murrow, H. N., Eckstrom, C. V., and Henke, D. W., "Development Flight Tests of the Viking Decelerator System," AIAA Paper 73-455, 1973.

${ }^{51}$ Dickinson, D., Schlemmer, J., Hicks, F., Michel, F., and Moog, R. D., "Balloon Launched Decelerator Test Program, PostFlight Test Report, BLDT Vehicle AV-1,"NASA CR-112176, 1972.

${ }^{52}$ Dickinson, D., Schlemmer, J., Hicks, F., Michel, F., and Moog, R. D., "Balloon Launched Decelerator Test Program, PostFlight Test Report, BLDT Vehicle AV-2,” NASA CR-112177, 1972.

${ }^{53}$ Dickinson, D., Schlemmer, J., Hicks, F., Michel, F., and Moog, R. D., "Balloon Launched Decelerator Test Program, PostFlight Test Report, BLDT Vehicle AV-3," NASA CR-112178, 1973

${ }^{54}$ Dickinson, D., Schlemmer, J., Hicks, F., Michel, F., and Moog, R. D., "Balloon Launched Decelerator Test Program, PostFlight Test Report, BLDT Vehicle AV-4,” NASA CR-112179, 1972.

${ }^{55}$ Moog, R. D. and Michel, F. C., "Balloon Launched Viking Decelerator Test Program Summary Report," NASA CR$112288,1973$.

${ }^{56}$ Raper, J. L., Lundstrom, R. R., and Michel, F. C., “The Viking Parachute Qualification Test Technique,” AIAA Paper 73$456,1973$. 
${ }^{57}$ Lundstrom, R. R., Raper, J. L., Bendura, R. J., and Shields, E. W., "Flight Tests of Viking Parachute System in Three Mach Number Regimes, Part I - Vehicle Description, Test Operations, and Performance,” NASA TN D-7692, 1974.

${ }^{58}$ Bendura, R. J., Lundstrom, R. R., Renfroe, P. G., and LeCroy, S. R., "Flight Tests of Viking Parachute System in Three Mach Number Regimes, Part II - Parachute Test Results," NASA TN D-7734, 1974.

${ }^{59}$ Moog, R. D., Bendura, R. J., Timmons, J. D., and Lau, R. A., "Qualification Tests of the Viking Decelerator System," Journal of Spacecraft and Rockets, Vol. 11, No. 3, 1974, pp. 188-195.

${ }^{60}$ Brecht, J. P., Pleasants, J. E., and Mehring, R. D., "The Viking Mortar: Design, Development, and Flight Qualification," AIAA Paper 73-458, 1973.

${ }^{61}$ Anon., "Viking Lander "As Built” Performance Capabilities," Martin Marietta Corp. Report, NASA Contract NAS1-9000, 1976.

${ }^{62}$ Ingoldby, R. N., Michel, F. C., Flaherty, T. M., Doty, M. G., Preston, B., Villyard, K. W., and Steele, R. D., "Entry Data Analysis for Viking Landers 1 and 2 - Final Report," NASA CR-159388, 1976.

${ }^{63}$ Brodsky, R. F. (ed.), Pioneer Venus - Case Study in Spacecraft Design, AIAA Professional Study Series, AIAA, Reston, Virginia, 1979.

${ }^{64}$ Talley, R. G., "Pioneer Venus Deceleration Module Final Report," General Electric, Re-entry Environmental Systems Division, Philadelphia, Pennsylvania, 1978.

${ }^{65}$ Nolte, L. J. and Sommer, S. C., "Probing a Planetary Atmosphere: Pioneer Venus Spacecraft Description," AIAA Paper 75-1160, 1975

${ }^{66}$ Rodier, R. W., Thuss, R. J., and Terhune, J. E., "Parachute Design for the Galileo Jupiter Entry Probe," AIAA Paper 81$1951,1981$.

${ }^{67}$ Vojvodich, N. S., Drean, R. J., Schaupp, R. W., and Farless, D. L., "Galileo Atmospheric Entry Probe Mission Description," AIAA Paper 83-0100, 1983.

${ }^{68}$ Corridan, R., Givens, J., and Kepley, B., "Transonic Wind Tunnel Investigation of the Galileo Probe Parachute Configuration," AIAA Paper 84-0823, 1984

${ }^{69}$ McMenamin, H. J. and Pochettino, L. R., “Galileo Parachute System Modification Program,” AIAA Paper 84-0824, 1984.

${ }^{70}$ McMenamin, H. J., "Galileo Parachute System Performance,” AIAA Paper 97-1510, 1997.

${ }^{71}$ Braun, R. D. and Manning, R. M., "Mars Exploration Entry, Descent, and Landing Challenges," IEEEAC Paper 0076, 2006.

${ }^{72}$ Fallon II, E. J., "System Design Overview of the Mars Pathfinder Decelerator Subsystem,” AIAA Paper 97-1511, 1997.

${ }^{73}$ Witkowski, A., "Mars Pathfinder Parachute System Performance," AIAA Paper 99-1701, 1999.

${ }^{74}$ Desai, P. N., Schofield, J. T., and Lisano, M. E., "Flight Reconstruction of the Mars Pathfinder Disk-Gap-Band Parachute Drag Coefficient," AIAA Paper 2003-2126, 2003.

${ }^{75}$ National Aeronautics and Space Administration, “1998 Mars Missions Press Kit,” NASA, 1998.

${ }^{76}$ JPL Special Review Board, "Report on the Loss of the Mars Polar Lander and Deep Space 2 Missions," JPL D-18709, 2000 .

${ }^{77}$ Witkowski, A., Kandis, M., Bruno, R., and Cruz, J. R., “Mars Exploration Rover Parachute System Performance,” AIAA Paper 2005-1605, 2005.

${ }^{78}$ Desai, P. N. and Knocke, P. C., "Mars Exploration Rovers Entry, Descent, and Landing Trajectory Analysis," AIAA Paper 2004-5092, 2004.

${ }^{79}$ Witkowski, A. and Bruno, R., "Mars Exploration Rover Parachute Decelerator System Program Overview," AIAA Paper 2003-2100, 2003.

${ }^{80}$ Steltzner, A., Desai, P., Lee, W., and Bruno, R., "The Mars Exploration Rovers Entry Descent and Landing and the Use of Aerodynamic Decelerators," AIAA Paper 2003-2125, 2003.

${ }^{81}$ Steltzner, A., Cruz, J., Bruno, R., and Mitcheltree, R., "Opportunities and Limitations in Low Earth Subsonic Testing for Qualification of Extraterrestrial Supersonic Parachute Designs,” AIAA Paper 2003-2135, 2003.

${ }^{82}$ Vasas, R. E. and Styner, J., "Mars Exploration Rover Parachute Mortar Deployer Development," AIAA Paper 2003-2137, 2003.

${ }^{83}$ Cruz, J. R., Mineck, R. E., Keller, D. F., and Bobskill, M. V., "Wind Tunnel Testing of Various Disk-Gap-Band Parachutes," AIAA Paper 2003-2129, 2003.

${ }^{84}$ Taeger, Y. and Witkowski, A., "A Summary of Dynamic Testing of the Mars Exploration Rover Parachute Decelerator System," AIAA Paper 2003-2127, 2003.

${ }^{85}$ Way, D. W., Desai, P. N., Engelund, W. C., Cruz, J. R., and Hughes, S. J., "Design and Analysis of the Drop Test Vehicle for the Mars Exploration Rover Parachute Structural Tests," AIAA Paper 2003-2128, 2003.

${ }^{86}$ Cruz, J. R., Kandis, M., and Witkowski, A., "Opening Loads Analyses for Various Disk-Gap-Band Parachutes," AIAA Paper 2003-2131, 2003.

${ }^{87}$ Zell, P. T., Cruz, J. R., and Witkowski, A., "Structural Testing of Parachutes in the National Full-Scale Aerodynamics Complex 80-by-120-foot Wind Tunnel at NASA Ames Research Center," AIAA Paper 2003-2130, 2003.

${ }^{88}$ Mitcheltree, R. A., "Dynamic Scaling for Earth Based Testing of Mars Terminal Descent Dynamics," AIAA Paper 20035391, 2003.

${ }^{89}$ Raiszadeh, B. and Queen, E. M., "Mars Exploration Rover Terminal Descent Mission Modeling and Simulation,” AAS 04271, 2004.

${ }^{90}$ Bonnefoy, R., Link D., et al., “Beagle 2 ESA/UK Commission of Inquiry,” 2004. 
${ }^{91}$ Fallon, E. J. and Sinclair, R., "Design and Development of the Main Parachute for the Beagle 2 Mars Lander," AIAA Paper 2003-2153, 2003.

${ }^{92}$ Haig, A., "Five Month Program for the New Main Parachute for the Beagle 2 Mars Lander," AIAA Paper 2003-2170, 2003.

${ }^{93}$ Northey, D., "The Main Parachute for the Beagle 2 Mars Lander," AIAA 2003-2171, 2003.

${ }^{94}$ Way, D. W., Powell, R. W., Chen, A., and Steltzner, A. D., "Asymptotic Parachute Performance Sensitivity," IEEEAC Paper 1465, 2005.

${ }^{95}$ Neal, M. F. and Wellings, P. J., "Descent Control Subsystem for the Huygens Probe,” AIAA Paper 95-1533, 1995.

${ }^{96}$ Lingard, J. S. and Underwood, J. C., "The Effect of Low Density Atmospheres on the Aerodynamic Coefficients of Parachutes," AIAA Paper 95-1556, 1995.

${ }^{97}$ Lingard, J. S. and Underwood, J. C., "Wind Tunnel Testing of Disk-Gap-Parachutes related to the Cassini Huygens Mission," AIAA Paper 93-1200, 1993.

${ }^{98}$ Underwood, J. C. and Sinclair, R. J. "Wind Tunnel Testing of Parachutes for the Huygens Probe," The Aeronautical Journal, October 1997.

${ }^{99}$ Underwood, J. C., "Development Testing of Disk-Gap-Band Parachutes for the Huygens Probe," AIAA Paper 95-1549, 1995.

${ }^{100}$ Underwood, J. C., “A System Drop Test of the Huygens Probe,” AIAA Paper 97-1429, 1997.

${ }^{101}$ Jäkel, E., Rideau, P., Nugteren, P. R., Underwood, J., Faucon, P., and Lebreton, J.-P., "Drop Test of the Huygens Probe from a Stratospheric Balloon," Advances in Space Research, Vol. 21, No. 7, 1998, pp. 1033-1039.

${ }^{102}$ Underwood, J.C. and Lingard, J.S., "Revalidation of the Huygens Descent Control Sub-System," Presented at the $2^{\text {nd }}$ International Planetary Probe Workshop, August 23 - 26, 2004, NASA Ames Conference Center, Moffett Field, California USA, 2004.

${ }^{103}$ National Aeronautics and Space Administration, "Genesis Sample Return Press Kit,” NASA, 2004.

${ }^{104}$ Haggard, R., Brown, G., and Corwin, R., "Parafoil Mid-Air Retrieval for Space Sample Return Missions," AIAA Paper 2001-2018, 2001.

${ }^{105}$ Ryschkewitsch, M., et al., "Genesis Mishap Investigation Board Report, Volume I,” NASA, 2005.

${ }^{106}$ National Aeronautics and Space Administration, "Stardust Sample Return Press Kit," NASA, 2006.

${ }^{107}$ Witkowski, A., "The Stardust Sample Return Capsule Parachute Recovery System," AIAA Paper 99-1741, 1999.

${ }^{108}$ Strickland J. H. and Higuchi H., "Parachute Aerodynamics: an Assessment of Prediction Capability (1995)," AIAA Paper 95-1531, 1995

${ }^{109}$ Klimas, P. C., "Internal Parachute Flows," Journal of Aircraft, Vol. 9, No. 4, 1972, pp. 313-314.

${ }^{110}$ Klimas, P. C., "Fluid Mass Associated with an Axisymmetric Parachute Canopy,” AIAA Paper 75-1352, 1975.

${ }^{111}$ Klimas, P. C., "Inflating Parachute Differential Pressures," Journal of Aircraft, Vol. 16, No. 12, 1979, p. 861.

${ }^{112}$ Meyer, J. and Purvis, J. W., "Vortex Lattice Theory Applied to Parachute Canopy Configurations," AIAA Paper 84-0795, 1984.

${ }^{113}$ Strickland, J. H., "On the Utilization of Vortex Methods for Parachute Aerodynamic Predictions," AIAA Paper 86-2455, 1986.

${ }^{114}$ Strickland, J. H., “A Vortex Panel Analysis of Circular-Arc Bluff Bodies in Unsteady Flow,” AIAA Paper 89-0930, 1989.

${ }^{115}$ Higuchi H. and Park W. C., "Computations of Flow Past Solid and Slotted Two Dimensional Bluff Bodies with Vortex Tracing Method," AIAA Paper 89-0929, 1989.

${ }^{116}$ Strickland, J. H., “A Prediction Method for Unsteady Axisymmetric Flow Over Parachutes,” AIAA Paper 93-1217, 1993.

${ }^{117}$ McCoy, H. H. and Werme, T. D., "Axisymmetric Vortex Lattice Methods Applied to Parachute Shapes," AIAA Paper 862456, 1986.

${ }^{118}$ Strickland, J. H., Homicz, G. F., Gossler, A. A., and Porter, V. L., "On the Development of a Gridless Inflation Code for Parachute Simulations," AIAA Paper 2001-2000, 2001.

${ }^{119}$ Strickland, J. H., Porter, V. L., and Homicz, G. F., "Fluid-Structure Coupling for Lightweight Flexible Bodies," AIAA Paper 2003-2157, 2003.

${ }^{120}$ Chatzikonstantinou, T., "Numerical Analysis of Three-Dimensional Non Rigid Wings,” AIAA Paper 89-907, 1989.

${ }^{121}$ Chatzikonstantinou, T., "Recent Advances in the Numerical Analysis of Ram Air Wings - The Three Dimensional Simulation Code 'PARA3D'," AIAA Paper 93-1203, 1993.

${ }^{122}$ Chatzikonstantinou, T., "Problems in Ram Air Wing Modeling and Their Solution in the Three Dimensional Simulation Code 'PARA3D'," AIAA Paper 99-1716, 1999.

${ }^{123}$ Barnette D. W., "Preliminary Numerical Simulations for Parachutes Using a Navier Stokes Solver on a Zoned Grid," AIAA Paper 91-0876, 1991.

${ }^{124}$ Nelsen, J. M., "Computational Fluid Dynamics Studies of Solid and Ribbon 12-Gore Parachute Canopies in Subsonic and Supersonic Flow," AIAA Paper 95-1558, 1995.

${ }^{125}$ Sahu, J., Cooper, G., and Benney R., “3-D Parachute Descent Analysis Using Coupled CFD and Structural Codes,” AIAA Paper 95-1580, 1995.

${ }^{126}$ Stein, K. R., Benney, R. J., Kalro, V., Johnson, A. A., and Tezduyar, T. E., "Parallel Computation of Parachute FluidStructure Interactions," AIAA Paper 97-1505, 1997.

${ }^{127}$ Stein, K. R., Benney, R. J., Tezduyar, T., Kalro, V., Leonard, J. W., and Accorsi, M. L., "3-D computation of Parachute Fluid-Structure Interactions - Performance and Control," AIAA Paper 99-1714, 1999. 
${ }^{128}$ Accorsi, M. L., Lu, K., Leonard, J. W., Benney, R. J., and Stein, K. R., "Issues in Parachute Structural Modeling Damping and Wrinkling," AIAA Paper 99-1729, 1999.

${ }^{129}$ Benney, R. J., Stein K. R., Tezduyar, T. E., Accorsi, M. L., Zhang, W., and Leonard, J. W., "Fluid-Structure Interaction Modeling of the U.S. Army Personnel Parachute System," AIAA Paper 2000-4310, 2000.

${ }^{130}$ Steeves, E. C., "Prediction of Decelerator Behavior Using Computational Fluid Dynamics," AIAA Paper 86-2457, 1986.

${ }^{131}$ Steeves, E. C., "Analysis of Decelerators in Motion Using Computational Fluid Dynamics," AIAA Paper 89-0931, 1989.

${ }^{132}$ Stein, K., "Computations of the Flow Characteristics of Aerodynamic Decelerators using Computational Fluid Dynamics," AIAA Paper 91-0866, 1991.

${ }^{133}$ Taylor, A. P., "An Investigation of Apparent Mass of Parachutes under Post Inflation Collapse Dynamic Loading Through the Use of Fluid Structure Interaction Simulations," AIAA Paper 2003-2104, 2003.

${ }^{134}$ Tutt, B. and Taylor, A. P., "The Use of LS- DYNA to Simulate the Inflation of a Parachute Canopy," AIAA Paper 2005$1608,2005$.

${ }^{135}$ Lingard, J. S. and Darley, M. G., "Simulation of Parachute Fluid Structure Interaction in Supersonic Flow," AIAA Paper 2005-1607, 2005.

${ }^{136}$ Cruz, J. R., Cianciolo, A. D., Powell, R. W., Simonsen, L. C., and Tolson, R. H., "Entry, Descent, and Landing Technology Concept Trade Study for Increasing Payload Mass to the Surface of Mars," Presented at the Association Aeronautique et Astronautique de France $4^{\text {th }}$ International Conference on Atmospheric Reentry Vehicles and Systems, Arcachon, France, March 2005.

${ }^{137}$ Witkowski, A., Machalick, W., and Taeger, Y., "Mars Subsonic Parachute Technology Task System Overview," AIAA Paper 2005-1657, 2005.

${ }^{138}$ Mitcheltree, R., Bruno, R., Slimko, E., Baffes, C., Konefat, E., and Witkowski, A., "High Altitude Test Program for a Mars Subsonic Parachute,” AIAA Paper 2005-1659, 2005.

${ }^{139}$ Brown, G. J., Epp, C., Graves, C., Lingard, J. S., Darley, M. G., "Hypercone Inflatable Supersonic Decelerator," AIAA Paper 2003-2167, 2003. 